Book Review

ISSN: 2162-3104 Print/ ISSN: 2166-3750 Online

Volume 5, Issue 4 (2015), pp. 545-546

(c) Journal of International Students

http://jistudents.org/

\title{
International Student in Japan
}

Premachandra, C. (2014). Having a Fulfilling Life as an International Student in Japan (English

Edition). Create Space Independent Publishing Platform. 102pp. Paper: \$17.00. ISBN: 9781496008879.

Reviewed by

Kyle D. Warren (Doctoral Student) and Eunyoung Kim, PhD, Seton Hall University (USA)

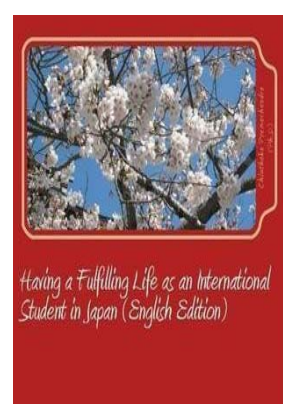

Since 1983, the Japanese government has worked to implement various reforms to make higher education in Japan more attractive to international students (Horie, 2002). Verbik and Lasanowski (2007) have identified Japan as an "evolving destination" (p. 14) in international mobility with a growing number of international students choosing to study in Japan.

In the book titled, Having a Fulfilling Life as an International Student in Japan, Chinthaka Premachandra presents readers with a guide to succeeding in the classroom and navigating other areas of the international student experience in Japan. In the first chapter, Premachandra discusses the importance of international students' Japanese language proficiency leading up to their studies. The author mentions that while there are some Japanese universities that use English as a medium of instruction in some classes, English speakers still need to focus on learning Japanese in order to be comfortable and successful during their time in Japan. In chapter 2, the author stresses the importance of learning the Japanese language during his discussion of enrollment into the six levels of study including Japanese Language School, Junior College, College of Technology, Professional Training College, University, and Graduate School.

Chapter 3 provides information for those who have an interest in continuing their education to the next level of study while in Japan. The author explains that the admissions process consists of an interview and either a written examination or a transfer by recommendation. As the interview is standard, Premachandra provides tips for a successful interview experience, including receiving feedback from professors and peers. In chapter 4, the author addresses classroom work and other academic concerns. He discusses the importance of registering for the correct courses, as many international students are not proficient with the Japanese language. The author warns that even those who attend Japanese Language School will likely have difficulty fully understanding the language and knowing the meaning of the many technical terms. Therefore, it is important for international students to follow up on lessons with classmates and professors to be sure that they understand important concepts.

Chapter 5 proves to be particularly informative as it introduces readers to research expectations at each level of study. The author highlights the expectation that students will conduct research at all levels, beginning with undergraduate study and possibly continuing 
research on the same topics as they progress to masters and doctoral studies. International students who enter Japan at the graduate level generally must spend time gaining research experience prior to being fully enrolled in a graduate program. In chapter 6, Premachandra provides information on the job search process that students might begin after completing studies at each level. He states that there are generally two ways to attain employment after completing one's studies: school recommendation and free application. Premachandra reiterates the importance of achieving excellent marks in school and highlights the critical role that Japanese language skills play in gaining employment because academic standing weighs heavily in the hiring process. After explaining the costs that are associated with education and job searching in Japan, the author dedicates chapter 7 to sharing introductory information on attaining scholarships. He notes several types of scholarships, including foreign government scholarships, Japanese government scholarships, scholarships provided by Japanese universities, and scholarships offered by private non-government organizations within Japan. Many of these scholarships are acquired through school recommendation, and there is a particular emphasis on academic excellence.

In chapter 8, the author answers questions about the type of housing available to international students as well as the process of obtaining housing while in Japan. The author shares information on school dormitories and regional international student halls that are embedded in cities. In addition, he mentions dormitories managed by private companies and the option of a homestay with a Japanese family, which can provide an international student with the opportunity to learn Japanese culture and norms. In the final substantive chapter, Premachandra discusses the processes associated with part-time work. He cautions that international students need to balance learning the language and completing course work and, therefore, should not attempt to work more than part-time and only if necessary. Premachandra continues to emphasize the importance of learning Japanese, reminding readers that language ability is also necessary for finding part-time employment.

In Having a Fulfilling Life as an International Student in Japan, based on his experience studying and working in Japan, Premachandra presents a guidebook that is brief, easy to read, and offers prefatory and practical information for international students at all postsecondary levels. While the intention of this brief manual is to assist students from all places and at all levels, this work would be strengthened significantly by focusing on one audience (e.g., international students at the graduate level). In less than 100 pages, the author attempts to cover many topics for many audiences. This means offering very little detail on any one specific issue and giving readers only brief and rudimentary information on topics related to their situations. The suggested audience for this book would include undergraduate students who are at the beginning stages of considering study abroad in Japan.

\section{References}

Horie, M. (2002). The internalization of higher education in Japan in the 1990s: A reconsideration. Higher Education, 43(1), 65-84. doi: 10.1023/A:1012920215615

Verkik, L., \& Lasanowski, V. (2007). International student mobility: Patterns and trends. The Observatory on Borderless Higher Education. Retrieved from http://www.obhe.ac.uk/documents/view_details?id=14 